\title{
\#MeToo - Implications for Criminal Law?
}

\author{
TATJANA HÖRNLE*
}

\section{Introduction}

A year has passed since the \#MeToo-movement gained force - an opportune moment for evaluating this social movement and its possible implications for criminal law. As it is hard to imagine that readers are not familiar with the term, explanations of \#MeToo can be kept short: After numerous allegations against the film producer Harvey Weinstein became public in October 2017, female actor Alyssa Milano came up with the idea to use 'MeToo' as a hashtag to spread messages via social media. The idea was to draw attention to the prevalence of sexual harassment and sexual assault. The \#MeToo-campaign rapidly attracted the attention of many persons who told their own stories and it had a remarkable impact on the fates of numerous powerful persons in the performing arts, politics and other areas of society. ${ }^{1}$ The campaign extended beyond simply using the two words 'me too' as a way to count victims. The point of what we know as \#MeToo is to tell stories in a more comprehensive way and to name and shame individuals for sexual misconduct. This naming and shaming has proven an effective tool that ruined the careers - and probably damaged the lives - of many accused. Wikipedia now lists an entry called the 'Weinstein effect', defined as a 'global trend in which people come forward to accuse famous or powerful men of sexual misconduct.'. The US news magazine Time, which each year chooses a person, a group, an idea, or an object that has done the most

* Professor of Criminal Law, Criminal Procedure, Comparative Law and Legal Philosophy, Humboldt-University Berlin. This article is based on the text of the Bergen Lecture 2018, October 3, 2018. Web addresses last checked on 14 October 2018.

1 See for a description of the events The New York Times (ed.), \#MeToo: Women Speak Out Against Sexual Assault (The New York Times Educational Publ. 2018).

2 https://en.wikipedia.org/wiki/Weinstein_effect

This is an Open-access article distributed under the terms of the Creative Commons Attribution 3.0 Unported License (http://creativecommons.org/licenses/ by/3.0/), permitting all use, distribution, and reproduction in any medium, provided the original work is properly cited. 
to influence the events of the year, assigned this position in 2017 to a group of women called The Silence Breakers. ${ }^{3}$

A year after, there are different ways to look at the \#MeToo-campaign. One might consider focusing on individual cases, recounting these stories and assessing the validity of the claims made by accusers and those who tried to defend themselves. This approach poses a lot of problems: there are too many stories to cover, even for a multi-paged book, and often the available information does not allow a reliable picture of the facts. This is one of the obvious problems with \#MeToo: for the users of Twitter and other social media, it is impossible to get a clear grasp of the facts. Another way to evaluate \#MeToo is to identify some more general features of the events. This will be the approach in the first part of this article. Within the scope of one article, it is not possible to evaluate the \#MeToo-campaign in a comprehensive way. Thus, I will limit myself to pointing out some positive and negative effects (section 2). From the viewpoint of legal sociology, the most interesting aspects are those that overlap with what the law is about. As an instrument of informal social control, \#MeToo can be assessed in a similar way as the formalised system of social control known as the criminal law. Relevant questions are, for instance: How effective was this movement for the prevention of sexual misconduct? Did it strengthen or change social norms of conduct for sexual encounters? Were blame and sanctions addressed to the right persons and did the blame match the wrongdoing?

In addition to the retrospective assessment of last year's events, I am interested in possible implications for the area of criminal policy: Would it be recommendable to extend or modify existing offence descriptions in criminal laws? This will be the topic for the second part of this article (sections 3-7).

\section{2. \#MeToo as a Mechanism of Informal Social Control}

\subsection{Creating Awareness}

The main achievement of the \#MeToo-campaign has been that it lifted the blanket of shame and encouraged people to share their personal experiences with others. Now, we do have a somewhat fuller picture of two facts: first, how frequent sexual misconduct was, especially within power relations; secondly, how it impacts the victims. The narratives of complainants increased awareness that being subjected to this kind of behaviour can be very unpleasant and harmful. From a legal perspective, the crucial point is that it is no longer necessary to explain why negative sexual freedom (the right to deny sexual inter- 
actions and to be protected against unwanted sexual acts) is an important interest, ${ }^{4}$ and why it should be protected both through informal social control and the criminal law.

\subsection{Changing and Strengthening Norms of Conduct}

Did the \#MeToo-campaign change norms of conduct that prescribe how human beings ought to behave when they wish to initiate sexual interactions? This is an empirical question, primarily a subject for social scientists. I have found only limited empirical data, ${ }^{5}$ but it seems likely that \#MeToo affected both the acceptance of social norms and individuals' disposition to act accordingly. At least as a working hypothesis, one can presume that the number of people has grown who insist that verbal sexual harassment and unwanted groping are unacceptable, not only at the workplace, but also in other social contexts. Others at least concede that it might be the most sensible strategy to avoid this kind of behaviour. Another question is how many actually follow these norms in their own personal conduct. Again, it is likely that \#MeToo had some preventive effects, also as a matter of deterrence. Witnessing the damaging effects of being publicly accused is likely to deter even some of those egocentric people who personally do not feel bound by social norms. Effective deterrence does not mean that every person stops harassing and abusing others - both the criminal law and informal social control can only strive to reduce misconduct.

How should tightened norms of conduct and behavioural changes be evaluated? Important positive aspects are beyond questioning: the more severe the unwanted sexual act is, and the more vulnerable the victim in its social context, the more it is evident that effective social prohibitions are desirable. Increasing the chances that rape does not happen is obviously a good idea. Positive effects are also evident with regard to assaults and 'offers' in professional and other social hierarchies, where people depend on bosses and others who decide about jobs, roles, projects, etc. No matter how coercive circumstances are evaluated in the context of criminal law (see section 6 below), from a social and psychological point of view, sexual proposals and groping ought to be avoided within hierarchical contexts. Men and women in the early stages of their professional lives should be spared anxieties and unpleasant sexual experiences. The \#MeToo-movement shed light on the emotional and psychological distress - not only for the targeted victims

$4 \quad$ Negative sexual freedom is different from positive sexual freedom, that is, the freedom to have sexual activities when, how and with whom one wants. The law can protect negative sexual freedom but it cannot protect human beings against the frustration of not getting what they want. Positive sexual freedom can only be promoted in a fragmentary way, by having less prohibitions (in comparison with traditional laws that prohibited sex outside of marriage and homosexual acts) but the law cannot grant citizens a satisfactory sexual life.

$5 \quad$ See for surveys Williams/Lebstock, Now What? Harvard Business Review (January 2018) pp. 3 ff., at p. 5 . 
but also for others who had to face difficult decisions of whether to intervene. ${ }^{6}$ From the public interest point of view, it is worth emphasising that the abuse of one's position to obtain sexual favours is a form of corruption. Sexual corruption can, like all forms of corruption and abuse of power, be detrimental to the quality of public services and artistic or scientific achievements. If skills and qualifications decide about access to careers and opportunities, the outcomes tend to be better than in the case of selfish, corrupted decision-making.

While important positive effects are hard to deny, some observers have also criticised the \#MeToo-movement. A group of French women, among them the actor Catherine Deneuve, has expressed reservations, arguing that \#MeToo enforces rigid puritan views and threatens sexual freedom for all, including women. ${ }^{7}$ Against this, the US-American author Siri Hustvedt argues that sensitivity and respect are essential conditions for a good erotic life. ${ }^{8}$ While Hustvedt's argument is certainly convincing, it does not grasp the full extent of possible negative side effects. Sexual misconduct is a very heterogeneous category. A more critical view might be appropriate if one turns to borderline cases of sexual harassment and to the indirect and unintended effects of enforcing rather strict rules against anything that could be perceived as harassment. Preventing sexual assaults and changing the behaviour of egocentric, selfish wrongdoers is laudable, but the intense public campaign can also impact men on the other side of the behavioural spectrum. My impression is that the discussions have caused a sense of insecurity way beyond Hollywood producers and other powerful men. In discussions about sexual offences, I have heard male students, who appeared to be nice and sensitive men, express puzzlement. These are men who want to do the right thing and who want to avoid annoying others. Their confusion is understandable. It is easy to describe what constitutes rape, sexual assault and sexual abuse. It is, however, not always easy to capture the concept of harassment. The difference between a pleasant flirt, an appreciated compliment, a funny joke with erotic undertones and the turning point where this becomes unpleasant and annoying, is not evident. In borderline cases, labels such as 'amusing' or 'harassment' depend on nuances, personal tastes, situations and moods. For concerned men (and others, too), in a climate of insecurity, it is a natural move to avoid borderline situations altogether and to maintain a strictly asexual climate of human interactions. It is legitimate to question whether this is a positive development, particularly if overly cautious behaviour becomes the norm beyond the workplace.

$6 \quad$ See for the latter point $i b i d$ at p. 3.

7 Open letter in Le Monde, see https://www.lemonde.fr/idees/article/2018/01/09/nousdefendons-une-liberte-d-importuner-indispensable-a-la-liberte-sexuelle_5239134_3232.html Interview with Siri Hustvedt, Frankfurter Allgemeine Zeitung, 8 September 2018. 


\subsection{Naming and Shaming Individuals}

If one turns from general social norms of conduct to the naming and shaming of individuals, problematic features of \#MeToo need to be mentioned. Before considering the negative aspects, some possible positive effects for complainants should be mentioned. As a criminal law theorist, I argue that victims of serious crimes have a legitimate interest that the state describes the wrong done and blames offenders through punishment. ${ }^{9}$ These legitimate interests cannot be fully served by the victims' own actions - a neutral third party (that is, a judge) is needed whose authority is acknowledged by the persons involved and by the general public. If the context is informal social control such as in the \#MeToo-context, there is no neutral third party with authority to fulfil the task of assessing accusations and according blame. From the psychological angle, it might nevertheless be regarded as 'better than nothing' if victims of serious sexual assault and harassment feel less helpless and perceive some sense of individual justice. \#MeToo created a chorus of voices to convey empathy and solidarity with victims, while the criminal justice system - with its much more formalised, purposely de-emotionalised procedures - may be perceived as cold and disinterested.

There is cause for concern, however, if one looks at the practices of \#MeToo from a perspective that is interested in procedural fairness and outcome-related justice. Of course, it would not be appropriate to evaluate mechanisms of informal social control according to the very strict standards developed for the criminal law - this would miss the crucial difference between these systems. However, it is fair to say that non-trivial sanctions deserve a critical procedural analysis and that unease is well founded if dubious procedures lead to serious consequences for the lives of individuals. Within the \#MeToo-movement, accusations and sanctions are inseparable. Exposing an individual as a wrongdoer in social media means not only to blame but also to sanction him at the same time. Naming and shaming under these circumstances is substantial hard treatment that cannot be reversed. The effects can be particularly damaging if intimate and sometimes embarrassing details of a person's sexual life are made public. Denunciations and revelations persist even if accused persons can defend themselves successfully in subsequent civil law suits or criminal trials. Within criminal procedure, a fundamental principle, the presumption of innocence, aims to minimise the effects of premature judgments. Under German law, television and other means of live recording are restricted in criminal

$9 \quad$ Hoernle, The Role of Victims' Rights in Punishment Theory in Penal Censure. Engagements Within and Beyond Desert Theory, eds. du Bois-Pedain and Bottoms (Hart Publ. 2019) pp. 207 ff. 
trials, ${ }^{10}$ the public can be excluded if embarrassing details are discussed ${ }^{11}$ and there are constraints on disclosing the names of accused persons. ${ }^{12}$ Social media can, however, not be effectively regulated, and there is no way to control the naming of alleged wrongdoers. Informal social control is not subject to any safeguards such as the presumption of innocence or restrictions on public exposure.

Evidence issues amplify the problems with unregulated naming and shaming. Accusations do not necessarily present facts in an accurate way. Observers of \#MeToo tend to assume that allegations by several complainants against the same person can be treated as trustworthy. As a rule of thumb, that might be justifiable, but it is not always a reliable rule. Even if accusations are similar, the underlying dynamics might be more complicated. The evidence problem is even more pressing if only one person claims to have been assaulted or harassed. Hierarchies and pressures of work life and in the competitive area of performing arts often cause high levels of personal frustration and interpersonal tensions. Ensuing conflicts might distort perceptions and memories of persons and events or even promote a straightforward desire for revenge. Grossly inaccurate or fabricated accusations are probably rare, ${ }^{13}$ but there must be some among the millions of allegations within the \#MeToo-campaign.

Even if there are no doubts concerning evidence, public naming and shaming can be disproportionate punishment in some cases. For milder forms of harassment, the responses can be too harsh - for instance, if the accused not only loses a life-defining job but also has no option for finding another similar position in the future. And reactions can be manifestly unfair if they harm third parties. Accusations that draw a lot of attention, mainly those against prominent persons, typically have tremendous impact on third parties too, such as the family of the accused or persons who feel guilty for not having

10 Sect. 169 Gerichtsverfassungsgesetz (Courts Constitution Act). The general prohibition was upheld after intense discussions, see Bundesverfassungsgericht (Federal Constitutional Court), BVerfGE 103 pp. 44 ff.; Rathmann in NK-ZPO, Saenger (ed.), 7th ed. (Nomos 2017) \$169 GVG para. 3; for new developments see https://www.loc.gov/law/foreign-news/article/germany-newlaw-allows-broadcasting-and-recording-of-court-proceedings. The exceptions from the rule (general prohibition) are rather narrow. It is still not allowed to broadcast criminal trials.

11 Sect. 171b Gerichtsverfassungsgesetz (Courts Constitution Act).

12 In Germany, the Federal Constitutional Court emphasises that the privacy rights of defendants must be carefully weighed against freedom of information and freedom of the press, Bundesverfassungsgericht (Federal Constitutional Court), BVerfGE 35 pp. 202 ff. = Neue Juristische Wochenschrift (NJW) 1973, pp. 1226, at pp. 1228 f.; BVerfG, NJW 2012 pp. 1500 ff.

13 With regard to formal complaints in criminal procedures, there is an ongoing discussion about how many accusations might be fabricated, see e.g. Schwenn, Fehlurteile und ihre Ursachen die Wiederaufnahme in Verfahren wegen sexuellen Missbrauchs, 30 Strafverteidiger (2010) pp. $705 \mathrm{ff}$., at 706; Lovett/Kelly, Different systems, similar outcomes? Tracking attrition in reported rape cases in eleven countries (2009) p. 60; Frommel, Begünstigen Opferschutzkampagnen Falschaussagen in Verfahren wegen sexueller Nötigung/Vergewaltigung? in Festschrift für Hans-Jürgen Kerner zum 70. Geburtstag, eds. Boers et al. (Mohr Siebeck 2013) pp. 697 ff. 
intervened (see the suicide of Jill Messick, the manager of the actress Rose McGowan in the Weinstein-case ${ }^{14}$ ). The public thunderstorms can also hit third parties that are not themselves accused of any sexual misconduct, see the recent resignation of Ian Buruma as editor of the New York Review of Books. ${ }^{15}$ These spillover effects are worrisome.

The foregoing criticism referred to dangers for the accused and other individuals in their surroundings. Other sets of concerns can be raised from different angles. If one focuses on the best interests of individual victims, it is not entirely clear that turning one's attention to past misconduct of others always is the best option. At least in reaction to milder cases, it might not be the best strategy for individual well-being to nurture the self-image of being a victim. Feminists have made a similar point: the emphasis on victimhood is not conducive to female empowerment. ${ }^{16}$ From the perspective of social psychology, if asked what is the best approach for societies, similar conclusions can be drawn. Even well organised societies will include some individuals with narcissistic personalities and/or low social intelligence and unpleasant manners. Up to a threshold of serious sexual misconduct, it might be the wiser approach to train resilience rather than invest a lot of energy into accusations. Moral arguments can be raised against naming and shaming, too. These responses can shed an unfavourable light on the accusers. The moral quality called politeness requires ignoring minor faults and deficiencies of others. Of course, this does not apply to sexual assault and sexual abuse, but to milder cases of offensive conduct, which might better be met with silence rather than stern public accusations.

Furthermore, the \#MeToo-movement promotes collective attitudes that do not deserve full and unambiguous praise, even if indignation is understandable when focusing on the individual case. Collectively shared satisfaction in 'bringing the powerful down' can have unpleasant undertones. Sometimes the line between self-empowerment and self-righteousness is a fine one. Another matter of concern is that the prominence of the \#MeToo-campaign might encourage others to take justice into their own hands across a range of different debated issues. As a general practice, it is hardly a beneficial development that groups use social media to orchestrate revenge against others. The widening gaps between different groups in our populations is a challenge for contemporary societies. The systematic use of social media to accuse and damage 'the other camp' requires critical scrutiny - but this leads beyond the topic to be covered here.

14 https://www.businessinsider.de/jill-messicks-family-statement-after-suicide-about-weinsteinmcgowan-and-metoo-2018-2?r=US\&IR=T

15 See https://www.theguardian.com/world/2018/sep/29/new-york-review-of-book-ian-burumajian-ghomeshi

16 Flasspöhler, Die potente Frau: Für eine neue Weiblichkeit (Ullstein 2018). 


\subsection{An Ambivalent Movement}

To summarise the preceding thoughts: If pressed on choosing between 'positive' and 'negative' to assess last year's \#MeToo-movement, I could not come up with a definite, clear-cut overall answer.

With regard to social norms of conduct, the positive effects are, all things considered, substantial. It is a praiseworthy development if social norms against sexual harassment, sexual assault and sexual corruption are more widely acknowledged and if deterrence works. This improves the safety and well-being of many individuals and reduces dysfunctional effects of corruptive practices for institutions and businesses. But a caveat is in order: strict norms that target minor cases of harassment outside of hierarchies and work places are questionable. A general climate of constrained, asexual relations might not be a positive development.

The naming and shaming of individuals deserves a more sceptical assessment. It comes with serious pitfalls, not only seen from the perspective of accused persons but also with regard to shared interests about how we should deal with each other. The initial idea to simply express 'me too' - just these two words - would not raise substantial objections. But the campaigns we have witnessed come with problems. Using social media for detailed accusations of individuals is a deeply ambivalent mode of exercising social control. I would strongly advice anyone who considers taking part in this movement to seriously think about matters such as fairness and proportionality, and to critically self-assess one's motives for participating.

\section{From \#MeToo to the Criminal Law}

While the \#MeToo-movement belongs to the realm of informal social control, it has, of course, implications for economics, organisational sociology and the law. How can work environments be organised to minimise harassment and sexual corruption? What kind of legal instruments should be chosen to suppress sexual misconduct at the workplace? Labour law has to deal with the latter question. Not working in this area of law, I have to apologise for skipping a large chunk of legal issues. Instead, I turn to regulations in substantive criminal law, with the following questions: Is there something the criminal law could learn from the \#MeToo-movement? Should we propose changes to existing criminal prohibitions?

Proposing legal reform is not a new demand. In Europe, we are in the middle of fundamental changes. If legal scholars and sociologists will write about the history of sexual offence law in the future, they certainly will include the \#MeToo-movement in the 
broader historical narrative. Legal changes, at least in the area of criminal law, hardly ever happen because some experts recommend them. Crucial components on the way to law reform are usually voices that publicly express dissatisfaction with the legal status quo. \#MeToo was, however, not the only or main causal factor for penal reform. Discussions among feminists, (other) academics, politicians and legislators started years before \#MeToo. When this social movement began in October 2017, some criminal laws had already been changed. A important turning point from the perspective of comparative law was the Sexual Offences Act 2003 in England and Wales. The German parliament passed the law that redesigned central norms on sexual assault and sexual abuse (Sections 177 and 179 of the German Criminal Code) in July 2016. ${ }^{17}$ Another important law reform took place recently in Sweden. Other European countries, such as Spain, consider reform. ${ }^{18}$ With regard to legal reforms in the future, the international \#MeToo-debate could be cited as one causal factor (other causal factors can be shocking cases such as the gang rape in Pamplona, Spain, in 2016 $\left.{ }^{19}\right)$.

In the following sections, I will argue from the perspective of criminal law theory rather than the perspective of comparative criminal law. This means that I will not compare details of existing criminal laws in a comprehensive way but focus on what a well-structured system of sexual offences should look like. The first step is to explain why traditional structures are in need of reform. A well-founded critique of the legal status quo must show how the law has evolved. Talking about legal history in our context is not merely a matter of academic discourse but an important starting point for demands to reform the law. The crucial point is that traditional versions of sexual offences are based on out-dated concepts. The next step is to reconceptualise wrongdoing. One of the insights I have gained from observing and participating in criminal law reform in Germany is: Law reform should proceed in distinct steps. First, the flaws of the existing law must be identified. In the political arena, this is often done by pointing to individual cases - cases where offenders did not get convicted or received a mild sanction, which was perceived as unjust. ${ }^{20}$ Such examples can be useful as a starting point for demanding reform, but an exclusively case-based analysis is too unsystematic. Feelings of injustice are not always shared by everybody. Secondly, it is essential to achieve clarity about the

18 See for a recent overview https://edition.cnn.com/2018/05/24/europe/sweden-rape-consentlaw-intl/index.html

19 See for the Pamplona case https://www.nytimes.com/2018/04/26/world/europe/spainpamplona-gang-rape-verdict.html

20 See for arguments in the German debate that referred to gaps in case law (Schutzlücken) Bundestagsdrucksache (Publications of the German Parliament) 18/8210 pp. 8 ff.; Grieger et al., Was Ihnen widerfahren ist, ist in Deutschland nicht strafbar: Fallanalyse zu bestehenden Schutzlücken in der Anwendung des deutschen Sexualstrafrechts (Bundesverband Frauenberatungsstellen und Frauennotrufe bff 2014) available at: https://www.frauen-gegengewalt.de/de/fallanalyse-zu-schutzluecken-im-sexualstrafrecht.html 
features of wrongdoing. In a third step, lawmakers must consider carefully the wording of offence descriptions. Reformulating offence descriptions can be a challenging task. It requires thinking carefully about how to classify and label offences and which terms are best suited to describe the wrongful conduct in offence descriptions. Changing one offence description will often impact the whole system of sexual offences in a criminal code. Thus, it is always necessary to consider systematics and overall consistency. Terminology can be tricky, too, because established terms such as Vergewaltigung in German law or voldtekt in Norwegian law are based on historical concepts (see section 4.1 below on the traditional notion that sexual offences require violence). Legislators need to find words that make sense both in our ordinary languages and in legal contexts and that are not impregnated with out-dated pre-understanding. I leave these intricacies of the third step in criminal law reform aside and focus on the second step, that is, the conceptual analysis of wrongdoing.

At this point, thinking about the criminal law, we must leave the \#MeToo-movement behind. This movement was driven by emotions: the anger of complainants and the indignation of many others who sympathised with them. Within a legal context, it is essential to de-emotionalise the debates and to move beyond an exclusive focus on victims' perspectives. Criminal prohibitions should be based on a fair balancing of what can be expected from citizens on both sides, that is, potential offenders and potential victims. The force of the \#MeToo-movement came at the cost of not having this kind of balanced analysis.

\section{The Traditional Model of Sexual Offences}

\subsection{A Very Brief Historical Overview}

To define sexual offences, laws or courts have always had to pay attention to the circumstances of sexual activities and to decide which kinds of sexual acts should be suppressed ${ }^{21}$ (also regarding matters of gender and marital status), and which conditions must precede the sexual act to carry the evaluation 'criminal wrongdoing. The second point is important for my subject. Traditionally, the law focused on what the offender had actively done prior to the sexual act and required an act with coercive impact. The core of wrongdoing as it appeared, for instance, in medieval laws was violence. Rape required that the offender applied violence in order to commit the sexual act. Also, the sexual transgression was

21 A society that did not aim for its own extinction could not have criminalised every instance of sexual conduct (at least not prior to the invention of human reproduction without sexual intercourse - in dystopian scenarios, a total ban on sex would be imaginable). 
initially restricted to vaginal intercourse that destroyed female virginity (or the reputation of being a 'honourable woman'). ${ }^{22}$ One reason for the traditional focus on violence was the low degree of sophistication regarding evidence in medieval trials - thus the necessity of witness reports about shouting and other observable signs of resistance. ${ }^{23}$ Another reason was that rape law had nothing to do with sexual autonomy but protected old-fashioned notions of female honour. ${ }^{24}$ In addition, the law, again since historical times, contained a second track of sexual offences, often labelled 'sexual abuse. ${ }^{25}$ The basic idea is that under certain circumstances violence is not necessary because the victim is not capable of defending herself. The classical scenarios were sexual intercourse with a sleeping woman or with a woman who had for other reasons lost consciousness. ${ }^{26}$ The prohibitions against sexual abuse played, however, a subordinate role. Under normal circumstances, the laws assumed that an honourable woman would defend her honour, and criminal wrongdoing thus required an act of the offender to overcome or pre-empt physical resistance.

The range of criminal liability expanded somewhat over the course of centuries. In the Criminal Code of the German Empire from 1871, the mere threat of violence complemented the exercise of actual violence. But the main point remained well into the $20^{\text {th }}$ century: legal definitions of rape and sexual assault required that the offender had actively done something to coerce the victim into obedience. His coercive acts could be violence or threatening the other person with violence or other serious negative consequences (see

22 See Art. 119 Constitutio Criminalis Carolina ('Notzucht'); Burgess-Jackson, History of Rape Law in A Most Detestable Crime: New Philosophical Essays On Rape, ed. Burgess-Jackson (Oxford University Press 1999) pp. 15, 17.

23 See for the importance of what was called 'Gerüfte' (loud shouting) Dane, Zeter und Mordio!: Vergewaltigung in Recht und Literatur (Wallstein Verlag 2005) p. 23.

24 Kratzer-Ceylan, Finalität, Widerstand, "Bescholtenheit" (Duncker \& Humblot 2015) pp. $109 \mathrm{ff}$.

25 See the headings of Sect. 174a-174c of the German Criminal Code and Sect. 179 (old version, prior to 2016).

26 Besides physical incapacitation, older laws already had acknowledged that sexual abuse can also occur through coercion by situation. In some institutional contexts, persons can be intimidated to a degree that others do not need to apply violence or threats in order to obtain sexual favours or passive obedience (see for instance Sect. 174 of the German Reichstrafgesetzbuch 1871, which criminalised sexual acts with teachers, foster parents, doctors in hospitals, etc.). 
Sect. 291 a) of the Norwegian Criminal Code: threatening conduct). ${ }^{27}$ Criminal laws in many European countries until today are based on this traditional model. The Norwegian criminal law could be called a semi-traditional model: a consent-based norm exists (Sect. 297), but the penalty (fine or imprisonment not exceeding one year) is rather low. The central norm in Sect. 291 with the heading 'voldtekt' still follows the traditional approach with its focus on violence, threat or incapacity.

\subsection{Flaws of the Traditional Model}

Sexual offences under the traditional model have one major flaw: they were not designed to protect sexual autonomy. One has to keep in mind that even the general notion of autonomy is a rather new development in human history. ${ }^{28}$ When it comes to the notion of sexual autonomy and particularly sexual autonomy for women, this point is even more important. Rules for sexual conduct were, for a long time, religious and/or moral rules but not instruments to protect the choices of individuals. In former times, it would have been considered a preposterous idea that disregard for an individual woman's wishes should be considered the core of wrongdoing. The invention of autonomy ${ }^{29}$ and the idea that the criminal law should protect individuals were fundamental shifts in our normative frameworks. The starting point today must be victims' autonomy, or more precisely, their right to negative sexual freedom. ${ }^{30}$

Such fundamental shifts make it necessary to re-examine criminal laws with older roots. Prima facie, it is not likely that laws not designed for the purpose of protecting sexual autonomy are well-suited to that purpose. Once normative premises have changed, the legal definitions of sexual offences should be re-considered in a genuinely fresh way, not burdened by traditional concepts. Legislatures in the post-war period in Europe did

27 In German law, until 2016, the crimes of sexual coercion and rape required physical force, explicit threats of physical injuries or victims' fear of physical injuries. Small additions to the traditional model came with the 33. Strafrechtsänderungsgesetz, 1 July 1997, BGBl. I p. 1607: between 1997 and 2017, Sect. 177 I Nr. 3 of the German Criminal Code contained the offence description 'coerces another person by exploiting a situation in which the victim is unprotected and at the mercy of the offender' (Nr. 1 and 2 contained the traditional 'coercion by force or by threat of imminent danger to life and limb'-clauses). This was meant to recognise that a victim's fear of physical violence does not always depend on the offender's explicit threats. However, until 2016, threats other than threats with physical violence were not included in the section on sexual offences in the German Criminal Code.

28 See Schneewind, The Invention of Autonomy (Cambridge University Press 1998).

29 See supra note 28 and Siedentorp, Inventing the Individual (Penguin Press 2015), for the even more groundbreaking normative shift towards the individual person.

30 See Hörnle, Sexuelle Selbstbestimmung: Bedeutung, Voraussetzungen und kriminalpolitische Forderungen, 127 Zeitschrift für die gesamten Strafrechtswissenschaften (ZStW) (2016) pp. 851 ff. 
not pay sufficient attention to this. For instance, the German legislator in 1974 revised the heading in the chapter of the Criminal Code on sexual offences, summarising them with the title 'protection of sexual autonomy'31 - however, without making the crucial step of reconsidering the offence descriptions. Legal reformers should start with the question: If we did not have criminal prohibitions against sexual misconduct, how should they be constructed? Lawyers and judges, but also law professors who write commentaries on existing criminal laws, are not used to the idea of designing laws from scratch. For behavioural scientists, the so-called status quo-effects are a familiar phenomenon. ${ }^{32}$ The same psychological phenomena can be observed if those who are trained to apply legal norms are asked to propose new norms - the bias in favour of the known is rather strong (perhaps even more pronounced among lawyers and judges than in other professions). In the discussions preceding the reform of the German criminal law in 2016, opponents of change argued that sexual autonomy was in fact fully protected by the old law: ${ }^{33} \mathrm{ei}$ ther persons are incapacitated or coerced with violence or threats, or they simply accept the other person's offer and sex becomes consensual sex. This view missed, however, the complexities of social reality, and it was conceptually flawed - lack of violence and lack of incapacitation does not equal consent. ${ }^{34}$

\section{New Paradigms for Defining Sexual Assault}

\subsection{Consent And Communication}

Redrafting criminal laws should begin with the insight that new paradigms must take centre stage for assessing sexual conduct as criminal wrongdoing. The traditional assessment focused exclusively on the moral wrong the offender has committed by actively coercing or abusing others. If laws aim to protect negative sexual freedom, the features that constitute the core of wrongdoing must be other circumstances than before. Cen-

31 4. Strafrechtsreformgesetz, 23 November 1973, BGBl. I p. 1725.

32 See for instance Samuelson/Zeckhauser, Status Quo Bias in Decision Making, 1 Journal of Risk and Uncertainty 1 (1988) pp. $7 \mathrm{ff}$.

33 Fischer, Noch einmal: $₫ 177$ StGB und die Istanbul-Konvention, 10 Zeitschrift für internationale Strafrechtsdogmatik (ZIS) (2015) pp. $312 \mathrm{ff}$., at pp. $318 \mathrm{f}$.

34 See for a critique of the old law Estrich, Real Rape (Harvard University Press 1988); Schulhofer, Unwanted Sex. The Culture of Intimidation and the Failure of Law (Harvard University Press 1998); Kratzer, Die Geschichte des Vergewaltigungstatbestandes - Aufbruch contra Konservierung, 93 Kritische Vierteljahresschrift für Gesetzgebung und Rechtswissenschaft (KritV) (2010), 83 (86 ff.); Hörnle, Warum $₫ 177$ Abs. 1 StGB durch einen neuen Tatbestand ergänzt werden sollte, 10 Zeitschrift für internationale Strafrechtsdogmatik (ZIS) (2015) pp. 206 ff. 
tral questions should be: What did the complainant want? Were his or her wishes based on non-deficient processes of decision-making? How did the complainant communicate with the other person? If the complainant expressed approval or did not express disapproval, were the sole grounds incapacity or a highly coercive situation? Shifting the focus does not mean that the offender's conduct no longer matters. The validity of the victim's consent and the relevance of coercive factors, can, of course, depend on what the offender did. But descriptions of an offender's conduct as coercion or abuse are only part of a broader and more complex analysis that should focus on the interaction between offender and victim.

If legislatures revise national criminal laws, they often rely on 'lack of consent' as the central element for sexual assault, see the English Sexual Offences Act 2003. According to newspaper reports, the Spanish government is planning a similar law reform..$^{35}$ The brand-new Swedish law used the expression frivilligt (voluntary). Unfortunately, it is not entirely clear what is meant when criminal laws refer to the victim's consent in offense descriptions. The notion of consent needs some clarification. One can understand consent and voluntariness as an inner mental state, and this seems to be the way it is understood in English law. ${ }^{36}$ On this interpretation, the decisive factor is what the victim truly wanted, while the question what they communicated only comes up with regard to evidence, as an indicator of the relevant inner mental state.

In my view, there are serious problems with a strong emphasis on inner mental states. First, there are problems with evidence. In some borderline cases, even an honest and thoughtful person might have problems deciding weeks or months later whether she really wanted this. The inner state of wanting something can be perceived as a clear and distinct state of consciousness, but this is not necessarily the case. If legal decisions can be made without the sometimes difficult reconstruction of subjective mental states, this is always the preferable option. Secondly, it is a matter of fairness to focus on communicated consent rather than on inner, unspoken attitudes. Modern criminal law can and should acknowledge not only duties for offenders, but also obligations for those who later claim to be victims of a crime. Psychologists and sociologists can explain why some persons, and particularly some women, might be reluctant to communicate their will openly in sexual contexts. ${ }^{37}$ The general line between rightful and wrongful conduct in the criminal law must, however, be drawn according to more standardised views of how citizens should behave and communicate with each other. From this point of view, the

35 https:/www.theguardian.com/world/2018/jul/18/spain-to-introduce-yes-means-yes-sexualconsent-law

36 Stevenson/Davies/Gunn, Blackstone's Guide to The Sexual Offences Act 2003 (Oxford University Press 2004) p. 9: 'Consent is absent where the person does not want to have sexual intercourse'.

37 Frith, Sexual scripts, sexual refusals and rape in Rape. Challenging contemporary thinking, eds. Horvath and Brown (Willan Publ. 2009) pp. 99 ff., at pp. $103 \mathrm{f}$. 
central concepts for modern criminal law on sexual offences should be consent and communication.

Both the new German criminal law and the new Swedish law acknowledge that communication matters. In German law, the central offence description requires that the adverse will must be recognisable (Sect. 177 I), and the legislative materials explain that the complainant's communication is of central importance for what was recognisable. ${ }^{38}$ In Swedish law (Swedish Criminal Code, Chap. 6 Sect. 1), this kind of explanation has made it into the law itself. Here, we find a clause that stipulates: when judging whether the participation was voluntary, it should be especially considered whether voluntariness has been expressed by word or act or in some other way.

\section{2 'No means No' or 'Only Yes means Yes'?}

What kind of communication should be required to mark the threshold between lawful and wrongful sexual acts? To understand the differences between the models under discussion, it is helpful to sketch different scenarios of communication. In the first scenario, all persons involved express their approval. This is the normal case of sexual interactions, but under certain circumstances it can still be sexual abuse (for instance, if one of the persons involved is a child). Second scenario: no communication took place because the later complainants could not communicate (cases of incapacitation). In the third type of scenario, the complainants communicated that they did not want sexual acts. Finally, the fourth scenario consists of cases where communication would have been possible but did not happen.

The third constellation (complainants communicated that they did not want sexual acts) and its legal consequences are summarised with the slogan 'No means no'. If criminal prohibitions aim to protect negative sexual freedom, criminal liability for the other person is appropriate. He or she must respect refusal expressed verbally or through unequivocal gestures or conduct, for instance, pushing the other away, crying, attempting to leave, etc. Communicating 'no' is a sufficient requirement. The criminal law does not need to ask, and should not bother with, the question: 'Why did the victim not do more than saying no?'. This was what the traditional approach did: blaming only offenders who prevented escape or physical resistance with force or threats. But again, the core of wrongdoing is the refusal to respect the right to negative sexual freedom, not threats or violence as such. Threats or violence enhance the severity of wrongdoing as additional elements but are not constitutive for the existence of wrongdoing.

The contemporary debate about law reform often focuses on the choice between a 'No means No' model and an 'Only Yes means Yes' model (affirmative consent). The dif- 
ference becomes relevant if one turns to the fourth scenario: the complainant could have communicated lack of consent to sexual acts, but did not do so. 'Could have communicated' is important - if the victim was sleeping, under anaesthetics or in a stupor due to intoxication, this is a case of incapacitation. Debated scenario four type-cases are those where an observer would describe the situation as unclear or ambivalent. The description 'unclear' or 'ambivalent' can fit if the persons involved had a prior friendly interaction (such as being on a date or friends spending time together) and, when confronted with a sexual proposal, one person either remains entirely passive (gives no negative or positive gestures at all) or switches back and forth between signals of consent and signals of dissent. Such behaviour would leave a hypothetical observer puzzled.

An 'Only Yes means Yes'-approach insists on affirmative consent. Lack of explicit consent means criminal liability for the other person. ${ }^{39}$ Under a 'No means No'-approach, truly ambivalent situations will not lead to criminal punishment. Before I defend the approach of the new German law, one point needs to be emphasised: Our topic is neither morality nor education. For moral rules, and specifically as a moral rule of conduct taught to teenagers, it might be a good idea to maintain high standards of considerateness and sensitivity, and to recommend asking if one is uncertain of the other's wishes. ${ }^{40}$ Different assessments are recommendable for criminal punishment, with its serious consequences for the future lives of convicted sex offenders (and also those who merely are accused of a sex crime). Within the context of criminal law, I emphasise in general, not just for sexual offences, both victims' rights and victims' obligations. ${ }^{41}$ The criminal law addresses citizens with citizens' responsibilities - on both sides of what might be later labelled a 'victim-offender-interaction'. Of course, criminal laws will not spell out victims' obligations explicitly. Offence descriptions only define what kind of conduct leads to criminal liability for offenders. But many definitions of criminal conduct implicitly require that victims have to behave in certain ways if the law later is to stipulate that they have been wronged. The crime of sexual assault should be formulated in a way that presumes an obligation to communicate. If the complainant is an adult and was able to think and express her will, any ambivalence can be dissolved easily: one simple 'no' or a gesture of rejection is sufficient. The demand to clarify one's wishes is a reasonable demand if the situation was truly ambiguous or if one has behaved in an inconsistent way. With regard to the

39 See for this approach Little, From No Means No to Yes Means Yes: The Rational Results of an Affirmative Consent Standard in Rape Law, 58 Vand. L. Rev. (2005) pp. 1321 ff.; Tuerkheimer, Affirmative Consent, 13 Ohio St. J. Crim. L. (2016) pp. 441 ff.; Anderson, Negotiating Sex, 78 S. Cal. L. Rev. (2005) pp. 1401 ff.; Herning/Illgner, 'Ja heißt Ja' - Konsensorientierter Ansatz im deutschen Sexualstrafrecht, 49 Zeitschrift für Rechtspolitik (ZRP) (2016) pp. 77 ff.; Dougherty, Yes Means Yes: Consent as Communication, 43 Philos. Public Aff. (2015) pp. $224 \mathrm{ff.}$

$40 \quad$ See for moral philosophy Dougherty (supra note 39).

$41 \quad$ Hörnle, Die Obliegenheit, sich selbst zu schützen, und ihre Bedeutung für das Strafrecht, 156 Goltdammer's Archiv (GA) (2009) pp. 626 ff.; Hörnle (supra note 9). 
other person, the stigma 'criminal wrongdoing' is too strong if the situation was unclear or ambivalent. It is one thing to understand difficulties with being straightforward and to judge the conduct of the more assertive (typically male) actor as insensitive (yes, indeed, he should have asked) - but it is another thing to declare this a criminal wrong.

The German solution in our new law is to combine a 'No means No'-approach as the standard feature with an 'Only Yes means Yes'-solution for some exceptional circumstances. In my view, this is a sensible compromise. The general idea is not to punish persons who initiated sex in unclear and ambivalent situations, which means that the law implicitly recognises an obligation to make an adverse will transparent. The relevant passage in the offence description is: 'against the recognisable will of another person' (Sect. 177 I of the German Criminal Code). ${ }^{42}$ If complainants argue that they did not want sexual acts, they have to accept the objection 'you should have communicated this'. However, judgments about what is fair to both sides shift if the complainant suffered from a handicap in judging the situation or responding adequately and if the offender took advantage of this. An obligation to communicate, as part of what can normally be expected from citizens, can only be assumed for adults with normal powers of judgment. If the complainant was severely drunk or mentally handicapped, and the offender took advantage of an ambivalent situation, German law applies an 'Only Yes means Yes'-approach (see Sect. 177 II Nr. 2 of the German Criminal Code). It is not prohibited to have sex with a drunk or mentally impaired person - but the other, more competent person must obtain approval. If she does not obtain approval, she will be charged for sexual assault even in the absence of an explicit 'no'.

\section{Coercive Circumstances}

The next points for discussion concern cases in which a 'yes' was expressed. Under certain conditions, voicing words such as 'yes' or 'ok, I'll do it' does not mean impunity for the offender. To mention an obvious example, saying 'ok' with a gun pointed to one's head cannot count as legally valid consent. The challenge for a communicative approach is to distinguish between communicated agreements that matter as valid consent, and verbal or other signs that are legally irrelevant.

With regard to our topic, the interesting question is: When does coercion exclude valid consent if adults agree to have sex in the context of a professional (or other) hierarchy? What should count as a situation that is similar to the gun-example? At this point,

42 Other offence descriptions (Sect. 177 II of the German Criminal Code) describe situations of incapacity (communication is not possible, for instance, if the sexual touching came fast and surprising or if the victim was not conscious, No. 1,3) and preemptive threats and coercive situations (No. 4, 5). 
we should return to the \#MeToo-movement for a minute. Some of the \#MeToo-cases obviously deserved the label 'sexual assault': if complainants said 'no' and the other person disregarded this, or if the event was a surprise attack that left no time for communication about the desirability of sex. What remains are the more difficult cases where the complainant had no personal desire to have sex but nevertheless chose to suppress disgust and expressed a 'yes'. The \#MeToo- narratives show that it is regarded as highly unfair if persons, in most cases men, utilise their professional and/or social power to obtain sexual favours. From a legal point of view, the mere description 'difference in power' is, however, not sufficient to categorise sexual acts as criminal offence.

Again, it is essential to distinguish clearly between empathy for the person under pressure and moral judgments on the one hand, legal judgments on the other hand. One positive feature of the \#MeToo-movement is that it sharpened awareness of how difficult it can be to express rejection if influential persons are in the position to make or destroy careers at their whim. From the point of morality, one might argue that it is a moral wrong to intrude into another person's sexual sphere if there is no indication that the other person feels attraction and desires physical contact. But even in the area of morality, there remains some space for discussions. Human beings sometimes agree to sexual interactions despite the fact that they did not really want sex for their own pleasure. Is it morally wrong to accept a favour from one's partner who is not really in the mood for sex, or to pay for the services of a prostitute? I will leave the moral conundrums aside but emphasise: Even if considered morally wrong, we should not conclude straightforwardly that the same kind of conduct must be prohibited by criminal law. For the purposes of the criminal law, it is necessary to pay attention to details.

Legal judgments should focus on self-responsibility and competence. We normally expect from citizens a minimum degree of self-responsibility. ${ }^{43}$ It should usually not be the task of the state to examine peoples' motives for consenting to sex. People may choose to accept or initiate sexual acts for motives that are not related to their own pleasure. Motives might be, for instance, a preference for avoiding conflicts, admiration for a prominent person, or expected financial, professional or social benefits. Only in exceptional cases should the law be interested in why someone agreed to sex: if the process of decision-making has been deficient, the assumption of self-responsibility might not be appropriate. Besides young age, intoxication, general cognitive impairment and mental diseases, legal assessments of this decision-making process rely on the concept of coercion. But what counts as coercion? Within moral philosophy, discussions about coercion

43 The German Federal Constitutional Court, referring to the human dignity-clause in Art. 1 I German Basic Law, emphasises self-responsibility as central for the constitutional view of human beings, see, for instance, BVerfGE 133 pp. 168 ff., at p. 197. 
are highly complex. ${ }^{44}$ For the criminal law, the task is somewhat easier: to identify the most severe cases where one person puts undue pressure on another.

To repeat: complainants' personal feelings that they have been coerced might be the starting point for closer examination but are not as such conclusive. One way to structure the normative analysis is to distinguish between coercion by act and coercion by situation. The easy cases are those where the offender initiates the turn from a professional or ordinary social encounter into a sexual encounter by announcing severe negative consequences for non-cooperation. Serious threats must not necessarily refer to physical violence - the announcement 'you will lose your job' counts, too. ${ }^{45}$ Under the influence of an offender's explicit serious threats, it does not count as legally valid consent if a complainant replies 'Ok, I'll do it'.

In the absence of coercion by act, how should one evaluate coercion by situation? What if it was understood, for instance, that the non-cooperating actress would probably not get the role she desperately wanted and needed? From a psychological point of view, this looks similar to the explicit 'you will be fired'-threat. Both complainants, the employee and the actress, would report to have felt under enormous pressure. From the legal point of view, one should, however, emphasise a distinction. Giving in to a sexual advance in order to improve one's prior position is different from doing so in order to prevent an unjustified worsening of a position one is legally entitled to have and keep. ${ }^{46}$ In other words: an employee who has a job contract can expect, under the protection of the law, to keep her job unless she violates professional duties. If the boss threatens to terminate the contract for reasons not related to work, this should count as a legally relevant coercive situation. The actress in my example is in a different situation. For her, agreeing to unwanted sex means to seize a chance to improve her situation, while the movie producer has no work-related duties towards her. I would draw the threshold here and not speak of a coercive situation in the legal sense if the threat concerns an omission without a legal duty to act. Under such circumstances, the labels 'sexual assault' or 'sexual abuse' do not fit. The criminal law has to protect individuals' liberties, and the possibility to improve one's situation through sexual favours can be seen as enlarging freedom rather than curtailing it. In the area of labour law and corporate law, there are other good reasons to be more restrictive and to prohibit sexual offers in hierarchies, in order to mi-

44 See, for instance, Wertheimer, Coercion (Princeton University Press 1989).

45 Some implicit threats deserve criminal punishment because it would not be convincing to ascribe responsibility to the victim. This is the case if an implicit threat of physical violence prompted the victim to endure sexual acts while remaining silent and uncommunicative. If it is known to both offender and victim that saying 'no' to a sexual proposal or sexual act would only mean that the offender resorts to physical violence, demanding that they nevertheless express disapproval would stretch victims' obligation too far. See Sect. 177 I Nr. 3 a.F. und Nr. 4 of the German Criminal Code.

46 See Wertheimer (supra note 44 ) at pp. $202 \mathrm{ff}$. 
nimise conflicts in work environments and to restrict sexual corruption and nepotism in the interest of third parties.

\section{Sexual Harassment}

The expression 'sexual harassment' in our daily language covers a wide range of conduct. It includes sexual physical contact but also a wider variety of non-physical intrusions, such as rude sexual jokes or sexual comments, pornography on a computer's screensaver in shared offices or pressure to date someone. In the case of physical contact, a separate offence description with the label 'sexual harassment' would not be strictly necessary - such cases could be categorised as sexual assault. However, this requires that the punishment ranges are flexible, that is, that the minimum punishment is not too high. With regard to the degree of wrongdoing, it makes a considerable difference if the sexual act was sexual intercourse or only putting a hand on a woman's breast. If legislatures have relatively high minimum punishment for sexual assault and want to reserve this label for serious misconduct, it makes sense to have an additional offence description for physical sexual harassment. This is now the German solution: Sect. 184i of the German Criminal Code covers groping; the punishment is much lower than for sexual assault. Despite the unspecified heading (Sexual Harassment) in Sect. 184i, the description requires physical contact between offender and victim and does not include verbal harassment.

Should modern criminal laws include prohibitions that cover verbal sexual harassment? In our ordinary language and in labour law, the wider understanding of 'sexual harassment' is common. Within the context of criminal law, it is questionable if this kind of conduct must be targeted, too. In my view, verbal sexual harassment and other forms of offensive conduct without intrusion into the physical sphere should not be an offence in the criminal law. I have emphasised at several points in this article that the criminal law has a distinctive role that must not be confused with broader moral and educational goals. Criminal law theorists use the Latin expression ultima ratio - that is, the criminal law as a last resort - to summarise this notion. An important reason supporting the $u l-$ tima ratio-principle is that criminal justice systems never have unlimited resources - it will always be necessary to use resources wisely and thus to focus on serious wrongdoing. And it is a matter of fairness towards potential defendants to restrict criminal prohibitions to those acts that are evidently wrong. Above (section 2.2), I have pointed out that it is not always possible to describe in a clear-cut way the boundary between, for instance, a funny joke with sexual content and a joke that the audience or parts of it consider offensive. Even if criminal courts could agree on the boundaries (which is unlikely), it is necessary to accept some leeway on matters of taste and considerateness in society. Em- 
ployers might have good reasons to strive for a harmonious atmosphere in work contexts and to prohibit all kinds of behaviour that might provoke complaints by some. But again, this can be left to the realm of labour law. In the public sphere and in people's private lives, the criminal law cannot serve as a universal cushion against unpleasant and insensitive fellows, and it should not be turned into an instrument for moral perfection.

\section{Final Remarks}

What can and should we infer from the \#MeToo-movement for the purpose of criminal policy? My answer is: not very much. It has been helpful to anchor some normative assessments more firmly within the general public, mainly that negative sexual freedom must be taken seriously. This is important because the traditional model of rape and sexual assault was not developed to protect negative sexual freedom. The step from \#MeToo to prohibitions in the criminal law requires, however, a lot of filtering. Emotions such as anger and indignation and also moral judgments should not be transferred straightforwardly into criminal prohibitions. What is needed is a normative analysis that recognises two premises: First, the limited role of the criminal law (the ultima ratio-principle). Secondly, the need to base offence descriptions on a well-balanced view of the liberties, duties and obligations between citizens, including obligations of potential victims. Criminal law theorists should invest more time into thinking about consent, communication and coercion. Legislatures should plan law reforms carefully. Legal reform requires a clear understanding of different models and concepts before drafting the details of offence descriptions. My experience with law reform in practice is that the reasoning of policy makers is often too superficial and/or proceeds too fast. It might be an advantage not to be the very first country in Europe to redesign sexual offences. If the Norwegian or other legislatures consider reform, this should be done after thorough preparation and with an eye to the experiences of other countries. 